Article

\title{
Using Remotely Sensed Imagery to Document How Land Use Drives Turbidity of Playa Waters in Texas
}

\author{
Scott M. Starr ${ }^{1}$, Lucas J. Heintzman ${ }^{1}$, Kevin R. Mulligan ${ }^{2}$, Lucia S. Barbato ${ }^{2}$ \\ and Nancy E. McIntyre ${ }^{1, *}$ \\ 1 Department of Biological Sciences, Texas Tech University, Lubbock, TX 79409-3131, USA; \\ scott.starr@ttu.edu (S.M.S.); lucas.heintzman@ttu.edu (L.J.H.) \\ 2 Center for Geospatial Technology, Department of Geosciences, Texas Tech University, Lubbock, \\ TX 79409-3132, USA; kevin.mulligan@ttu.edu (K.R.M.); lucia.barbato@ttu.edu (L.S.B.) \\ * Correspondence: nancy.mcintyre@ttu.edu; Tel.: +1-806-834-7977
}

Academic Editors: Javier Bustamante, Alfredo R. Huete, Patricia Kandus, Ricardo Díaz-Delgado and Prasad S. Thenkabail

Received: 13 December 2015; Accepted: 18 February 2016; Published: 26 February 2016

\begin{abstract}
Sedimentation (primarily from human land use) is a major threat to runoff-fed wetlands of the Great Plains of North America (playas), but it is unknown how many playas are turbid, how prevalence of turbidity has changed over time, and how turbidity is related to surrounding land use. We used remotely sensed imagery to assess sedimentation in the waters of over 7700 playa basins in Texas on four dates during a 29-year span: 25 July 1986 (a regionally wet time), 3 May 2014 (during drought), 4 June 2014 (after the drought was broken), and 25 July 2015 (one year post-drought). Even on the wettest date examined, $64 \%$ of playa basins did not hold water. Turbidity varied over time, was already present in over half of the basins examined in 1986, and prevalence of turbidity was not simply proportional to overall wet playa abundance. There was an increase in total and irrigated cropland in our focal region and a statistically significant association between sedimentation and land use within $100 \mathrm{~m}$ of a playa: clear playas were associated with more urban development and pasture/grassland, and turbid playas were surrounded mostly by cropland.
\end{abstract}

Keywords: agriculture; cropland; cultivation; drought; Landsat; precipitation; rainfall; sedimentation

\section{Introduction}

\subsection{Background and Rationale}

Sedimentation is a consequence of erosion and a key threat to aquatic ecosystems worldwide [1,2]. Runoff-fed (i.e., depressional) wetlands are inherently susceptible to sedimentation and are particularly vulnerable when their watersheds experience accelerated rates of erosion due to anthropogenic activities such as land-cover change [3,4]. For instance, playas are depressional wetlands of the tablelands of the central and southern Great Plains of North America that are foci for biodiversity $[5,6]$ and are highly impacted by land-cover changes stemming from agriculture [7]. There are $>30,000$ of these wetlands in the U.S., comprising a habitat network for migratory, breeding, and overwintering wildlife, including much of the continent's waterfowl, waterbirds, and shorebirds [7].

The playa network of the Great Plains of North America is akin to other depressional wetland complexes around the world (particularly in arid and semi-arid regions) that are experiencing land-cover change, including the prairie potholes of the northern Great Plains, vernal pools of the northeastern U.S., and wetlands of Spain, India, Brazil, southern Africa, and central Asia [7-12]. Elsewhere in the world, the term playa may be used to refer to a shallow, saline waterbody [8]. In the 
Great Plains of North America, however, the term playa is typically reserved for freshwater wetlands that are fed solely by precipitation runoff and that lose water by infiltration and evapotranspiration; any Great Plains playas that are groundwater-fed or are saline are generally known by a different term, salina or saline lake [7]. Furthermore, whereas many other playa networks around the world are experiencing effects due to flooding and salinization associated with irrigation, the playas of North America are relatively less affected by an excess of water. We will therefore use the term playa to refer to shallow (typically $<2 \mathrm{~m}$ in depth), flat-bottomed, seasonal freshwater wetlands of the Great Plains of North America [7].

Most playas ( $\sim 87 \%)$ are smaller than 12 ha in surface area, with watersheds averaging 55.5 ha (range: 0.8-267 ha) [13]. Each playa occupies an independent, closed-basin watershed and is distinctive (in the field, in aerial photographs, and in remotely sensed imagery) even when dry due to a characteristic hydric soil basin [14] and associated vegetation [7]. The majority of playas of the Great Plains occur in the Texas panhandle [7], where large-scale, irrigated agriculture began in the 1930s-1940s and accelerated in intensity and distribution after extensive groundwater mining of the Ogallala Aquifer began after World War II $[15,16]$. Currently, this region is approximately $26 \%-32 \%$ tilled (and typically irrigated) cropland and 36\%-42\% non-irrigated pasture or grassland (including former cropland currently enrolled in the Conservation Reserve Program) [17], although some counties exceed $80 \%$ of land under cultivation [18], and an estimated $90 \%$ of playas in this region have at least some portion of their watershed under cultivation [7]. Changes in irrigation practices were initiated in the 1980s, with a transition from row-flood (furrow) irrigation to the current practices of center-pivot and drip irrigation [19]. Whereas row-flood irrigation generated a great deal of runoff, much of which wound up in playas, modern practices are more water-thrifty, meaning that playas no longer receive as many supplementary inputs from irrigation as they did at the peak of irrigation in our region, in the mid-1970s [20].

Land use, particularly that associated with irrigated annual tillage agriculture in this region, creates an environment that facilitates playa sedimentation, with sediment loads being positively associated with cultivation [21,22]. In this region, agricultural fields are often bare soil (no cover crop) in the non-growing seasons; these bare fields are subject to erosion for over half the year, and are the primary source of sediments that wind up in playa basins. In a field survey of 40 dry playas (i.e., basins with no water currently in them) in Texas, sediment depths at the soil surface ranged from 17 to $1049 \mathrm{~mm}$ (mean = $249 \mathrm{~mm}$ ) and were deeper playas surrounded by tilled cropland [21]; similar sediment depths (means ranging from 230 to $380 \mathrm{~mm}$ ) have been found in the Rainwater Basin playas of Nebraska [23]. The sediments that accumulate in playas have been found to be from waterborne rather than windborne particles, resulting from watershed erosion that is exacerbated in croplands that are irrigated relative to non-irrigated agricultural fields [24]. Sediment accumulation causes playas to fill with earth, thereby losing volumetric capacity to hold water: Luo et al. [25] found that playas surrounded by cropland had 8.5 times more sediment in soil cores (taken when playas were dry) than did those surrounded by rangeland (grazed grassland), resulting in a loss of $\geqslant 100 \%$ of basin volume for cropland playas vs. 30\% volume loss for grassland playas. Some of the water that enters the playa basin does not accumulate, being displaced by sediment infill and spilling into the non-hydric soils in the surrounding uplands, where it infiltrates or evaporates [26]. This water is not a significant source of aquifer recharge because of an impermeable caliche layer that occurs in the region except under playas, making playas the primary source for groundwater recharge [7]. Similar effects of cultivation on sediment loads have been seen in the Rainwater Basin wetlands of Nebraska [27] and the prairie potholes of the northern Great Plains [3].

This sediment accumulation has caused some playas to be lost altogether, being no longer apparent as depressions that pond water [28]. Because hydric soils can be buried by sediments, some playas have also been "lost" due to soil reclassification [29]. The presence of such sediments can cause the basins to no longer pond water (the sediments displace water as well as absorb water), but reclassification reflects a semantic loss in playa numbers that can preclude legal wetland protection or allocation of funds for 
wetland conservation or restoration [7]. Playa loss rates range from $17 \%$ to $85.7 \%$ [17,28,29], with this wide range reflecting differences in methodology and region. For example, Johnson et al. [28] compared historic ( 1970) and more recent (2008) aerial imagery for 602 playas in Texas and New Mexico to estimate that $\sim 17 \%$ of basins in the southern Great Plains were filled entirely (no depression remaining) and $\sim 60 \%$ no longer held water despite the presence of a depression. Similarly, Collins et al. [17] used satellite imagery to examine 8404 playa basins in Texas over a four-year period (2008-2011) and determined that 4078 basins (i.e., 51.5\%) never held water, even after above-average precipitation. In both of these studies, land conversion for tillage agriculture was implicated as the ultimate cause of sediment accumulation that led to basin infill and impaired ability to pond water. As a consequence, sedimentation from land conversion has been deemed a more serious threat to playas than a $5{ }^{\circ} \mathrm{C}$ rise from climate change [30] or climate change-driven shifts in precipitation amount and intensity [31]. Indeed, a significant number of playas have already been estimated to be filled with sediment, with most playas projected to be filled completely within a century if no mitigation is done [31].

Based on the occurrence and depths of non-hydric soils burying hydric soils, accelerated sedimentation associated with agricultural practices from the 20th century onwards is deemed a threat to the continued existence and ecological functioning of playas [19,30]. These assessments were based on soil cores taken from a relatively small number of dry basins [21,24-26,32]. We, however, were more interested in sedimentation in water, which is likely to incur unique biological impacts; quantifying sedimentation in water (i.e., turbidity) has not been attempted in this system. Sedimentation in water results in increased turbidity; in playas, this turbidity is fine-grained inorganic matter held in colloidal suspension from persistently windy conditions [33], rather than organic, algae-derived turbidity [34,35]. Most prior remote sensing studies of turbidity have focused on non-mineral sources of turbidity, mainly chlorophyll $a$ [34-37]; our focus was on inorganic suspended sediments. The suspended sediments in playas typically do not settle out, resulting in persistently cloudy water that is tan in color and readily distinguished from clear water in playas (e.g., via use of a Secchi disk). For example, turbidity in nephelometric turbidity units (NTUs) measured as per EPA Method 180.1 [38] in cloudy water from playas in the Texas panhandle averaged ( \pm standard error) $849 \pm 172$ (range: 10.3-9744), whereas clear playas were $37.8 \pm 8.1$ (range: 2.0-394) (N.E.M. data from 2009 to 2014). Similar values are reported in Smith [7] of 20-2860 NTUs, although these were not classified as "clear" or "turbid." Turbidity can lead to numerous negative biotic effects (reviewed in Henley et al. [39]). For example, sediments can bury seed- and invertebrate egg-banks [40-42]. Turbid water is negatively associated with aquatic plant diversity [43] and can cause die-offs of benthic macrophytes, resulting in disruption of ecosystem function [44]. Increased sedimentation reduces wetland hydroperiod [26], leading to a decrease in bird diversity [45] and a change in amphibian community composition [46]. Finally, values above 30-45 NTUs are known to limit fish foraging efficiency [47]. However, there are no threshold turbidity values for overall biological effects or ecological impairment, likely because such effects vary by species, source of turbidity (inorganic vs. organic origins), or other factors.

Sedimentation present on the soil surface within a playa basin that accumulates while the playa is dry may or may not cloud water after a precipitation event fills a playa, because such sediments may be relatively stable compared to those carried in via runoff. Because playas are intermittent wetlands [7], they experience extensive dry periods (indeed, they are dry more often than they hold water). When there is sufficient rainfall to fill playas, the question becomes to what degree the playa waters are sedimented (i.e., turbid), and how that is related to the land use in a playa's watershed. We therefore conducted a large-scale, longitudinal remote-sensing assessment of these temporally dynamic wetlands to quantify land-cover change effects on the inputs of terrestrial sediments into aquatic systems. Unlike previous assessments of playa sedimentation, which were field-based and thus subject to logistical constraints on sample sizes (e.g., Luo et al. [24]—40 playas; Luo et al. [25]—eight playas; Tsai et al. [21] -33 playas; Tsai et al. [26] -70 playas; and Gitz et al. [32]—six playas), we used remotely sensed imagery to examine sedimentation in a much larger number of basins with more extensive spatial coverage. 


\subsection{Objectives}

Our objectives were to quantify how many playas in this region are currently turbid, how the prevalence of turbidity has changed over time, and how turbidity is related to land use surrounding a playa. Although a remote sensing approach has been taken to examine turbidity (primarily from algal growth rather than inorganic sediments) in various other wetland types (e.g., estuaries, rivers, man-made and natural lakes; [34,48-50]) (reviewed in [51]), to our knowledge, ours is the first assessment for playa waters. Because sedimentation from land conversion from native grassland to irrigated, tilled agriculture is considered to be the main driver affecting playa volume, hydroperiod, and thus ecosystem value [30], a quantitative assessment of land use on suspended mineral sediments in playa waters is clearly warranted.

\section{Materials and Methods}

\subsection{Study Area}

We examined playa inundation and changes in occurrence and prevalence of sedimentation in a time series of Landsat WRS-2 path/row 30/37 (hereafter, scene 30/37; Figure 1) images in Texas across four dates: 25 July 1986 (during a regionally wet span of several weeks), before (3 May 2014) and after (4 June 2014) several rainfall events occurred beginning on 21 May 2014 that broke a severe drought and filled playas in the region, and then a follow-up a year later (25 July 2015). These dates were chosen to represent as large a span of time as possible with available cloud-free, high-quality imagery. The 1986 image was taken with Landsat 5 Thematic Mapper (which stopped operating in November 2011), and the 2014-2015 images were from Landsat 8 Operational Land Imager (which began operating in April 2013). Whereas the Landsat 5 images were approximately $182 \mathrm{~km} \times 190 \mathrm{~km}$, the Landsat 8 images were approximately $190 \mathrm{~km} \times 195 \mathrm{~km}$ but covered most of the same region and so are given the same path/row identifier by the USGS (30/37 in this case). The Landsat 8 images ultimately covered a slightly larger area than the Landsat 5 image, thereby including an area that contained more playa basins (Figure 1). Because of these differences in area and numbers of playas, comparisons among dates are of proportions of wet playa basins within each scene, and proportions of clear vs. turbid playas.

Our study area experiences a rainy season from April through September. Rainfall data were obtained for the National Weather Service's Forecast Office at the Lubbock International Airport (with Lubbock being the largest populated place within scene 30/37; Figure 1). The area averages $468.1 \mathrm{~mm}$ of annual rainfall (long-term average from 1911 to 2013 [52]). By the time the 25 July 1986 image was taken, the area had already received over $5 \mathrm{~mm}$ more than its expected average precipitation, primarily from rainfall in the preceding month, which saw nearly double the monthly norm. The 25 July 1986 image we used should thus show a relatively high number of wet playa basins. Beginning in 2011, the region began experiencing "exceptional drought," with that year recording the lowest annual rainfall since record-keeping began in 1911 [53]. Beginning in January 2011 until 21 May 2014, the area received only $774.7 \mathrm{~mm}$ of precipitation, about half of the $1506.9 \mathrm{~mm}$ long-term average expected for that span. During this worst drought on record, most playas in the region were dry until rains began on 21 May 2014. Thus, our 3 May 2014 image should have very few wet playas present. Between 21 May and 3 June 2014, $132.8 \mathrm{~mm}$ of rain fell (on just 6 days within that 14-day span), representing over $28 \%$ of the $468.1 \mathrm{~mm}$ annual average. This amount of rain filled many playas in the region, some for the first time in at least four years. Thus, our 4 June 2014 image should have a relatively large number of wet playas present. Between 4 June 2014 and 25 July 2015, there was $977.1 \mathrm{~mm}$ of precipitation, well above the $604.5 \mathrm{~mm}$ long-term average. Thus, our 25 July 2015 image should also show a relatively large number of wet playas. 


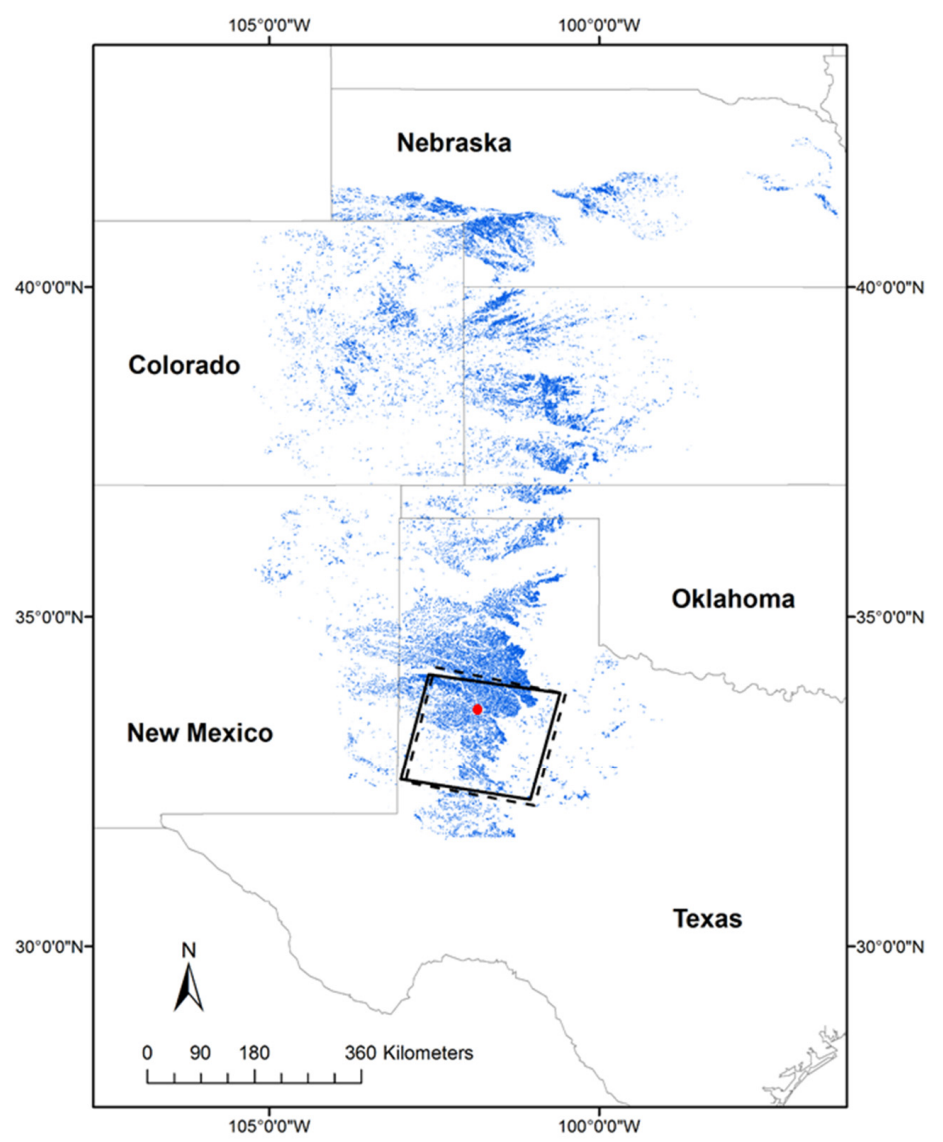

Figure 1. The occurrence of playas (blue) in the U.S. and our focal area (Landsat scene 30/37), showing the difference in coverage between satellites/dates (Landsat 5 TM: solid outline; Landsat 8 OLI: dashed outline) in Texas. Playa locations are from the Playa Lakes Joint Venture [54] to show the full extent of playas in the U.S., which extends beyond the boundary of the Playa Wetlands Database (Texas, Oklahoma, New Mexico) used in our project. The location of Lubbock (largest populated place within scene $30 / 37$ ) is shown as the red dot.

\subsection{Approach}

We used the four satellite images to examine changes in the prevalence of sedimentation over a 29-year span in our study area, and to then relate prevalence (and any changes in a given basin's status between clear/turbid among dates) to surrounding land-cover type. From the four dates we examined, there was a relatively old satellite image from 1986 from a wet time that we suspected should show fewer sedimented playas than more recent images taken after 28 more years of irrigated tilled agriculture, a recent image during severe drought, a recent image from a wet time immediately after the drought when fresh sedimentation should have been at its most recent, and a recent image also during a wet time after sediments may have had a chance to settle out.

Our workflow process was as follows: (1) download suitable satellite imagery and clip to a common spatial extent; (2) use a band-math classification rule in ENVI software to distinguish water from non-water cells in each of the images, thereby creating binary classified images; (3) bring these binary classified images into ArcMap software and rasterize them; (4) use ArcMap to overlay a pre-existing raster mask of known playa basin locations onto the binary classified images to separate wet playa cells from dry playa cells, and to clip away all non-playa cells; (5) use Raster Calculator in ArcMap to associate only the wet cells with each playa basin's unique ID code to create a "wet cells" shapefile for each of our four dates; (6) overlay the "wet cells" shapefile in ArcMap onto the original Landsat image for each of our four dates to extract the digital satellite data from only the 
portions of each playa that were wet (ignoring dry playa areas and wet non-playa areas); (7) use a band ratio classification in ArcMap to distinguish clear from turbid wet cells within each playa basin; (8) perform an independent accuracy assessment of our sedimentation classification method (see Uncertainties, Errors, and Accuracies section); (9) obtain county-level land-cover data from the USDA's Census of Agriculture for 1987 and 2012 to examine relatively coarse temporal and spatial land-cover trends in our study area over time; (10) obtain 30-m resolution land-cover data from the USDA's National Agricultural Statistics Service CropScape for 2014 to examine finer-scaled land-cover trends; (11) reclassify the CropScape data from >100 to eight land-cover categories; (12) use ArcMap to create $100 \mathrm{~m}$ buffers around each playa basin and extract the CropScape data from within the buffer; (13) tally the number of clear and sedimented wet cells within each playa basin to designate a majority classification for each basin as overall clear or turbid; (14) quantify prevalence of sedimentation at each of our four focal dates; (15) quantify changes in prevalence of sedimentation over time in our study area; and (16) perform a chi-squared statistical analysis to examine whether either classification status (clear or turbid) was related to the types of land cover within $100 \mathrm{~m}$. Each of these steps is explained in the Methods section below.

\subsection{Methods}

All four of the satellite images we used were cloudless ( $0 \%$ cloud cover), of maximal quality (9), and downloaded from the USGS Landsat archive [55]. Although there was an image taken on 19 May 2014 immediately prior to the end of the drought, it had extensive cloud coverage (47\%) and so was not used. Similarly, dates following 4 June 2014 were cloudy until August 2014, by which time some playas had already dried and refilled from subsequent rains. Because of orbital variation in satellite flight path, the three images we used from Landsat 8 (the two 2014 and one 2015 images) were stacked and then clipped to the area that was covered in all three images (i.e., common to all three images). Moreover, the Landsat 5 image (from 1986) was clipped to remove "noise" found at the image edges (i.e., the ragged edge that is typical of Landsat scenes); the clipping process for the Landsat 8 images had the same result.

Satellite imagery processing followed the protocols developed by Collins et al. [17]. The digital satellite data (i.e., optical band data) were first calibrated to top of atmosphere reflectance in ENVI 5.1 software (Exelis Visual Information Solutions, Inc.; Boulder, CO, USA). Playas were identified in ENVI 5.1 and 5.2 with a band math wetland classification rule with a modification made for the Landsat 8 images rather than Landsat 5 as used in Collins et al. [17]; multispectral bands 6 and 4 were used for the Landsat 8 images, and bands 5 and 3 were used for the Landsat 5 image to correspond to the appropriate short-wave infrared and visible red spectra used to distinguish water from non-water. This technique is one of the most common means of identifying water in remotely sensed images [34,35,56,57].

The four classified images were then converted to shapefiles projected to UTM zone $14 \mathrm{~N}$ (geographic coordinate system NAD 1983, datum WGS 1984) in ArcMap 10.2.2 (Esri; Redlands, CA, USA). Non-playa waters (e.g., rivers, wastewater-treatment facilities, etc.) were removed by rasterizing the shapefiles and overlaying a rasterized mask of playa basin locations $\geqslant 0.03$ ha from the Playas and Wetlands Database (PWD [52]). The digital data of the PWD cover a 52-county area of Texas, New Mexico, and Oklahoma, derived from three sources [58,59]: (1) playa-specific (hydric) soils for wetlands $\geqslant 0.11$ ha detected during county soil surveys conducted by the Soil Conservation Service/National Resource Conservation Service from 1959 to 1998 [60] and from the Soil Survey Geographic Database; (2) aerial images with $1 \mathrm{~m}$ (0.0001 ha) resolution from the 2004 National Aerial Imagery Program; and (3) aerial imagery from the 2004 U.S. Fish and Wildlife Service's National Wetlands Inventory, with wetlands delineated at a resolution of $\sim 0.04$ ha. We extracted the 21,893 playa basins from the PWD (separating them from the 42,833 other wetlands in the PWD consisting of impoundments, lakes, manmade waters, riparian areas, saline lakes, scrub or other, and unclassified wetlands; see Mulligan et al. [59] for descriptions) and then clipped the extent to the same area as our Landsat 
images, with playas touching the border being included in their entirety. This allowed us to determine how many playas were inundated on each date out of the number of playa basins present within the focal area. We did so via the Raster Calculator function in the Spatial Analyst extension in ArcMap, which resulted in a binary layer where wet areas within playa basins were coded with each basin's unique identification number, and other cells (dry playas or wet non-playas) were coded as no data (see Collins et al. [17] for methodological details). These layers were then converted into "wet cells" shapefiles representing wet areas within playas that were overlaid onto the Landsat images to extract data from only the water-covered areas within playa basins on each date. The relatively few wet playa basins present in May 2014 were also inspected with finer-resolution Google Earth imagery (imagery dates from April 2013-November 2014) to detect any factors accounting for their presence as wet during a period of exceptional drought.

To catalogue playa waters as sedimented (i.e., turbid) or not (i.e., clear), we used a binary classification operation performed in ArcMap (Raster Calculator) comparing bands of visible red and visible blue light to distinguish clear from turbid wet cells within each playa (Figure 2). For Landsat 8 , these were bands 4 (visible red: $0.64-0.67 \mu \mathrm{m}$ ) and 2 (visible blue: $0.45-0.51 \mu \mathrm{m}$ ), whereas for Landsat 5 it was bands 3 (visible red: $0.63-0.69 \mu \mathrm{m}$ ) and 1 (visible blue: $0.45-0.52 \mu \mathrm{m}$ ). These bands were chosen based on previous studies that showed that the ratio of these wavelengths were most useful in separating turbid from clear water [34,35,61,62]. For the 2014 and 2015 (Landsat 8) images, the ratio of bands 4:2 clearly distinguished turbid from clear waters, whereas for the 1986 (Landsat 5) image, the ratio of 1:3 was more successful, possibly because the image was "greener" overall, and some of the sedimented playas had a greenish cast that could have been related to either the presence of algae or the overall greenish cast to the Landsat image. We performed an independent assessment of this method's accuracy (see the Uncertainties, Errors, and Accuracies section) and were highly satisfied with its performance.

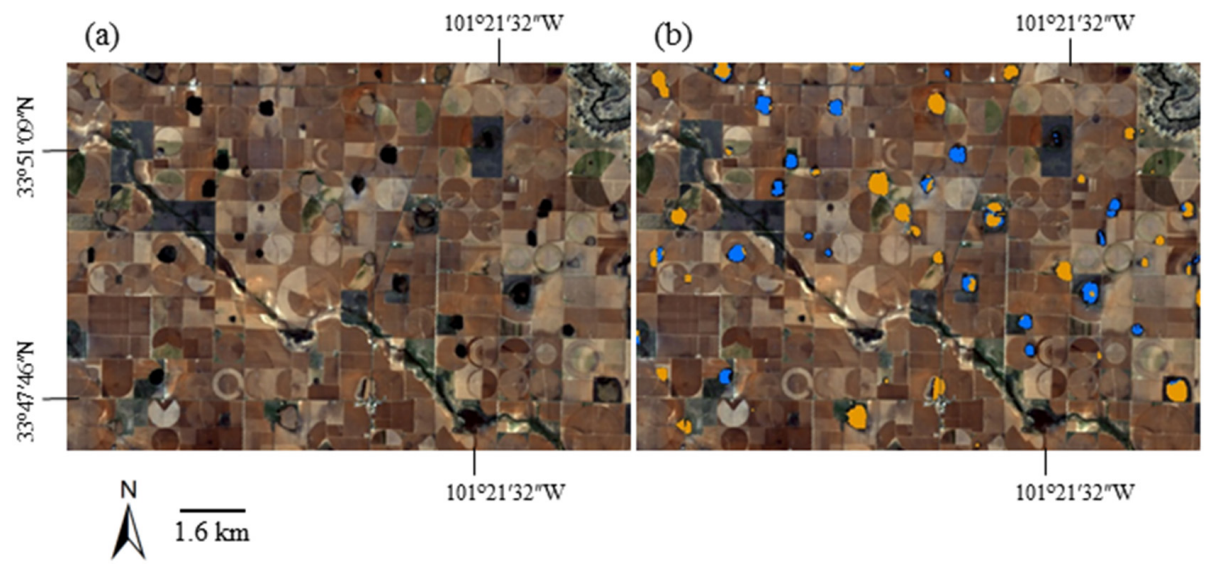

Figure 2. (a) Examples of turbid and clear playas and surrounding land use on 4 June 2014; (b) Examples of playa waters from Figure 2a classified as clear (blue) or turbid (orange). Notice how some playa basins contained both clear and turbid portions.

To examine effects of land use on inundation and sedimentation, we used two complementary datasets. At a relatively broad scale, we used the USDA's Census of Agriculture [18] to examine land-use trends over time. These data are collected every five years and reported at the county level, so we obtained data from the censuses closest in time to our two temporal endpoints (the 1987 and 2012 censuses) for the ten counties in Texas that have the majority or entirety of their land area within scene 30/37. We used these data to determine whether and how the amount of cropland in our focal region changed over time. Finer-resolution $(30 \mathrm{~m})$ digital agricultural data are available annually for Texas from 2008-present from the USDA's National Agricultural Statistics Service CropScape data [63], which we used to conduct a finer-scaled analysis for our two 2014 dates. CropScape data consists of 
over 100 land-use categories, 42 of which occurred in scene 30/37. Most categories are different types of agricultural crops, such as cotton, sorghum, etc., which we reclassified to an eight-category system (cropland, pasture/grassland, shrubland, forest, developed, barren, wetland vegetation, and open water), following the methods in Collins et al. [17].

The proportion of each of these categories was calculated within a 100-m buffer around each playa's hydric soil-defined basin. A 100-m buffer has been used in several playa studies, largely because the density of playas precludes use of larger buffers without experiencing extensive buffer overlap and thus lack of spatial data independence $[17,57,64]$. Playa basins or buffers that fell on the scene boundary were included in their entirety. To calculate land use within each buffered area, we created eight separate raster layers for each of the land-use categories, where each raster cell was associated with either that land use or coded as "no data" (i.e., belonged to one of the other land-use categories), and joined these with a raster layer of the playa buffers for each date, where each cell was associated with either a unique playa basin ID number or coded as "no data" (for cells outside a playa). We then could calculate the proportions of the eight land-use categories in each playa's buffer, and also designate the majority land-use type surrounding each playa. Because there was heterogeneity of sedimentation within a basin (meaning that a given playa could contain both turbid and clear cells), we used a majority rule (i.e., a basin's modal value) to designate a playa's water as sedimented or not overall.

All data layers were raster/rasterized at $30 \mathrm{~m}$ resolution. We conducted a Pearson's chi-squared $\left(\chi^{2}\right)$ analysis in SAS 9.4 (SAS Institute, Cary, NC, USA) to examine whether a playa's status as clear or sedimented was related to the dominant surrounding land-use type in 2014. We also examined the proportion of playas with turbid waters as a function of longer land-use trends by examining differences between the most recent and the oldest dates (a 29-year span) with respect to amount of total cropland present, amount of irrigated cropland present, and proportion of playas classified as turbid.

\section{Results}

The area in scene $30 / 37$ that was common to both satellites was $33,074.6 \mathrm{~km}^{2}$ and contained 7747 playa basins. There were 7921 playa basins within the area covered by Landsat 5 (1986 image) and 8372 basins within the area covered by Landsat 8 (2014 and 2015 images) (Table 1). Fewer than half of these basins were wet at any given time, however. For example, on 25 July 1986 (a relatively wet time), only $26.9 \%$ of the basins contained water. During the drought in 2014 , less than $1 \%$ of the basins contained water on 3 May 2014; this increased to 32.6\% of the basins containing water on 4 June 2014 when the drought was broken. A year later (25 July 2015), even more basins (36.0\%) held water. This indicates, however, that $64.0 \%$ of playa basins in our focal area did not hold detectable water even during the wettest date examined. This number is comparable to the findings of Ruiz et al. [65] for Landsat 5 TM scene 30/36 (just north of our focal area): they found that fewer than half of the 8404 playa basins in their study area ever held water over 37 dates spanning a five-year period, with a maximum of $2955(35.2 \%$ ) basins wet on a single date (and a minimum of $127=1.5 \%$ ).

Table 1. Summary information for each of our focal images.

\begin{tabular}{ccccc}
\hline Date & 25 July 1986 & 3 May 2014 & 4 June 2014 & 25 July 2015 \\
\hline Satellite & Landsat 5 TM & Landsat 8 OLI & Landsat 8 OLI & Landsat 8 OLI \\
\hline No. of playa basins present & 7921 & 8372 & 8372 & 8372 \\
No. of wet playas & 2128 & 82 & 2730 & 3015 \\
No. of turbid wet playas & 1270 & 25 & 1925 & 1553 \\
\hline
\end{tabular}

During the drought (3 May 2014 image), 91.4\% of the relatively few wet playas present were associated with urban development (34 playas) or other human modifications (41 playas) that increase hydroperiod (such as construction of pits, inflow channels, etc.); this illustrates the outsized role that 
urban playa basins play in holding what little water is available during drought. Collins et al. [17] similarly found that playa hydroperiod was positively associated with human modifications and urban land use. However, urban playas are not ecologically equivalent to non-urban ("natural") playas in terms of hydroperiod, depth, water chemistry, and other factors [7].

On 25 July 1986, 59.7\% of the wet playas were classified as turbid (Table 1). Of the 82 playa basins that contained water on 3 May 2014, 30.5\% were determined to be turbid. This percentage increased to $70.5 \%$ on 4 June 2014, when 2730 playas were wet and 1925 of those were turbid. This increase was expected, given that precipitation runoff is the primary means by which sedimentation occurs. A year later on 25 July 2015, 51.5\% of the playas were turbid. There was thus no increasing trend in sedimentation over time, with most playa basins already being impacted by sedimentation by the mid-1980s. Furthermore, the prevalence of turbidity was not simply proportional to the number of wet playas present (Table 1). When individual playas were tracked over time, most did not change their classification, although a few went from clear to turbid, or from turbid to clear. For example, there were 1345 playa basins that were wet on both the endpoint dates (1986 and 2015); most of these did not change status (i.e., clear playas stayed clear, turbid ones stayed turbid). However, 216 basins that were clear in 1986 became turbid by 2015, and 285 went from turbid to clear during that span. A similar pattern was seen during and immediately after the drought in 2014 (only 18 out of 82 playas that were wet in both May and June changed status, with 11 changing from clear to turbid and 7 changing from turbid to clear). Therefore, despite the colloidal nature of playa sediments, playa turbidity is something that can change over the span of only a month (e.g., a heavy input of rainfall runoff that has low/no sediment load can dilute and clarify turbid waters, and runoff with a heavy sediment load can do the opposite). This result is a promising find for remediation prospects.

Table 2. Amounts (in hectares (ha) and in percent of total county area) of total cropland and irrigated cropland in the ten counties of Texas contained entirely or predominantly within our focal satellite scene (Landsat 30/37). Data are from the 1987 and 2012 USDA Census of Agriculture. The "-" indicate that those data were not available for that county in that year.

\begin{tabular}{|c|c|c|c|c|c|c|c|c|c|}
\hline \multirow{2}{*}{$\begin{array}{l}\text { County } \\
\text { Borden }\end{array}$} & \multirow{2}{*}{$\begin{array}{c}\begin{array}{c}\text { County } \\
\text { Area (ha) }\end{array} \\
234,653\end{array}$} & \multicolumn{4}{|c|}{1987} & \multicolumn{4}{|c|}{2012} \\
\hline & & $25,575.32$ & 10.90 & - & - & $25,519.90$ & 10.88 & 2007.29 & 0.86 \\
\hline Crosby & 233,617 & $121,676.02$ & 52.08 & $33,981.78$ & 14.55 & $121,241.00$ & 51.90 & $45,231.98$ & 19.36 \\
\hline Dawson & 233,617 & $182,220.23$ & 78.00 & 7621.46 & 3.26 & $194,738.00$ & 83.36 & $24,758.70$ & 10.60 \\
\hline Hockley & 235,430 & $154,889.79$ & 65.79 & $30,370.85$ & 12.90 & $161,923.00$ & 68.78 & $43,285.42$ & 18.39 \\
\hline Lamb & 263,661 & $162,683.22$ & 61.70 & $72,161.11$ & 27.37 & $189,924.64$ & 72.03 & $72,653.62$ & 27.55 \\
\hline Lubbock & 233,358 & $166,144.10$ & 71.20 & $50,090.69$ & 21.47 & $171,518.00$ & 73.50 & $62,940.08$ & 26.97 \\
\hline Lynn & 231,286 & $137,096.16$ & 59.28 & $12,468.02$ & 5.39 & $164,567.00$ & 71.15 & $28,987.45$ & 12.53 \\
\hline Terry & 230,768 & $156,360.42$ & 67.76 & $32,946.96$ & 14.28 & $152,557.00$ & 66.11 & $397,763.92$ & 17.24 \\
\hline
\end{tabular}

The Census of Agriculture showed that the amount of cropland declined between 1987 and 2012. However, in a few counties in our focal area there was an overall increase in agricultural land, especially in irrigated cropland (Tables 2 and 3). We expected the prevalence of turbidity to follow these increases, but it did not. This is likely due to the fact that the majority of our study region was already cropland by the mid-1980s, favoring sediment accrual and turbidity in 1986. Irrigated agriculture peaked in this region in the mid-1970s and then declined for a variety of reasons [20]. When land cover was examined at a finer scale, in both of the 2014 dates examined, most playas (both clear and turbid) were surrounded by cropland (not surprising given that this is an agriculturally dominated region), followed by pasture/grassland, developed, shrubland, and wetland vegetation. Barren, forest, and open water land-use types were rare. There was a statistically significant effect of the dominant land-use type within $100 \mathrm{~m}$ of a playa on whether a playa's water was clear or sedimented for both May $\left(\chi^{2}=10.75, d f=3, p=0.0131\right)$ and June $\left(\chi^{2}=102.76, d f=4, p<0.0001\right)$ in 2014. Clear playas 
had more urban development and pasture/grassland within $100 \mathrm{~m}$, and sedimented playas were surrounded by mostly cropland (Figure 3 ).

Table 3. Change in amounts (in hectares (ha) and in percent of total county area) of total cropland and irrigated cropland areas in the ten counties of Texas contained entirely or predominantly within our focal satellite scene (Landsat 30/37). Data are from the 1987 and 2012 USDA Census of Agriculture. The "-" indicate that because those data were not available for that county in 1987, and thus changes could not be calculated.

\begin{tabular}{ccccc}
\hline County & 2012-1987 Total Cropland Area (ha) (\%) & 2012-1987 Irrigated Area (ha) (\%) \\
\hline Borden & -55.44 & -0.02 & - & - \\
Crosby & -434.63 & -0.19 & $11,250.20$ & 4.82 \\
Dawson & $12,517.33$ & 5.36 & $17,137.24$ & 7.34 \\
Gaines & $17,918.67$ & 4.60 & $27,267.20$ & 7.0 \\
Garza & -5450.31 & -2.35 & 2619.03 & 1.13 \\
Hockley & 7033.03 & 2.99 & $12,914.57$ & 5.49 \\
Lamb & $27,241.38$ & 10.33 & 492.51 & 0.18 \\
Lubbock & 5373.82 & 2.30 & $12,849.39$ & 5.51 \\
Lynn & $27,471.28$ & 11.88 & $16,519.43$ & 7.14 \\
Terry & -3803.64 & -1.65 & 6829.96 & 2.96 \\
\hline
\end{tabular}
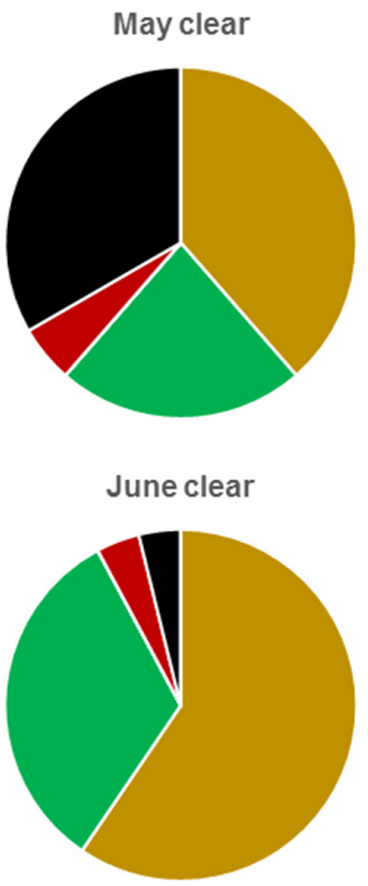

Cropland

Pasture/grassland

Developed
May sedimented

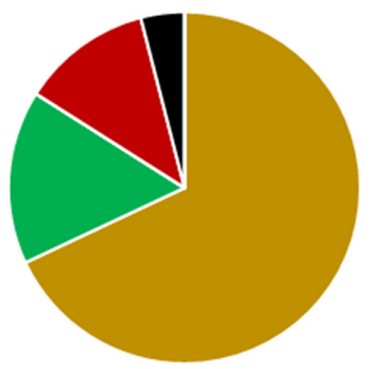

June sedimented

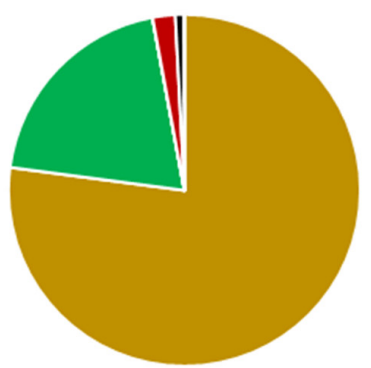

Shrubland

Wetland vegetation

Figure 3. Pie charts of the proportions of the dominant land use surrounding playas classified as clear (left) or sedimented (right) in May (top) and June (bottom) 2014. The wetland vegetation land-use category was the dominant land-use type for only a single playa (one classified as turbid, 4 June 2014) and so is not readily apparent in the figure. The other land-use categories (barren, forest, and open water) were not the dominant land-use type for any playa and so are not depicted in the legend. 


\section{Discussion}

Most playa basins in our focal region did not hold water, even after substantial rain. Of those playa basins that did pond water, most were turbid on most of the dates (except during the drought), thus confirming the suspicion (based on previous studies that examined soil cores) that most playa waters of our focal region are impacted by sedimentation. Playas are shallow, typically $<2 \mathrm{~m}$ in depth [7], although urban playas are often deepened for recreation or flood management to depths $>3 \mathrm{~m}$. It is thus possible that shallower playas (i.e., those associated with non-urban land-use types) may have been scored as turbid more frequently than warranted because the basin (the ground) could be seen through clear but shallow water. However, our results support the model predictions of Burris and Skagen [31], who estimated that most playa basins in our focal region would have been filled with sediments prior to 2010. It should be noted that their study was parameterized with Luo's [16] 40 playa soil samples from Texas (20 cropland, 20 pasture/grassland) and then extrapolated across the entire playa region. Although their modeling methods were sound, they were not cross-validated or otherwise empirically calibrated. Our results thus provide a sort of independent validation of their findings.

Cultivation is both positively [66-69] and negatively [17,21,26,57] associated with playa inundation and hydroperiod: on the one hand, tilled rows can facilitate overland flow of runoff, allowing playas to fill (albeit with heavy sediment loads), but on the other hand, growing vegetation can physically block and absorb water and sediments [4]. Thus, whereas cropland playas may fill more readily, they contain turbid water compared to playas with grass-dominated watersheds. Sediment infill should reduce hydroperiod, but we were unable to confirm that in this study because of limitations of the available Landsat imagery. The satellite transit is at a 16-day interval, and subsequent images after 4 June 2014 were cloud-covered (which precludes analysis) for the next two months. During that time, there were several rain events in some portions of the study area (recall that rains began on 21 May 2014, meaning that the 4 June 2014 image is the first date on which an assessment of hydroperiod could begin). It is currently unknown how much rainfall it takes to fill a playa, being dependent on surrounding land cover as well as watershed size, but occurrence of rain during the transit interval precludes use of remotely sensed imagery to examine effects of sedimentation on hydroperiod in our data. Although satellite imagery has been used to examine playa hydroperiod [17], that study acknowledged the limitations of such a coarse temporal scale of analysis.

Burris and Skagen [31] predicted that, based on past and current sedimentation rates in cropland and grassland playas, almost $90 \%$ of playas in the Great Plains ( $75 \%$ in Texas) would be completely infilled with sediments by 2100 , and that this was more influenced by projected land use than by projected changes in precipitation. Sedimentation is effectively irreversible without anthropogenic intervention [69]. Sediment removal is a difficult and costly task but is currently the only effective means of sedimentation remediation [7]. Prevention (e.g., via grass buffers) can be effective [70], but vegetation that blocks sediment flow also blocks and absorbs water, reducing the probability of inundation, water volume, and hydroperiod length [64,66-69]. Playas in urban areas were generally clear, especially those in grassy parks (although they may experience other reductions in water quality). Playas surrounded by grassland were generally clear as well. Thus, a grass buffer may help reduce sedimentation in playas [70-72]. Playas are unique and irreplaceable ecological resources that are being affected by land conversion. Agriculture and urban growth, however, are irreplaceable economic activities. Therefore, compromise must be achieved; use of grass buffers to ameliorate sedimentation may be a fruitful area for future research.

\section{Uncertainties, Errors, and Accuracies}

We compared our ArcMap band-math classification results against a k-means unsupervised classification (similar to the approach in Sawaya et al. [61]) where we first stacked the TIF files associated with Landsat bands 1-7 (0.43-2.29 $\mu \mathrm{m})$ in ERDAS Imagine 2014 and 2015 (Hexagon Geospatial; Norcross, GA, USA) to create a single image file per date, using the 1986 date and the two 2014 dates as 
test cases. We then used the "wet cells" shapefile as an area-of-interest mask to extract the reflectance values from these images from only those wet areas within playas, creating images showing just the playa waters and not the surrounding land or dry playa areas. We refined 15 initial clusters down to two based on consensus by three of the authors (Scott M. Starr, Lucas J. Heintzman and Nancy E. McIntyre) of a cell's categorization as turbid (brown) or clear (blue to black) via inspection of the playa water data layer (e.g., as in Figure 2a).

We overlaid the binary results from the two methods (band ratio in ArcMap and unsupervised classification from ERDAS) and used Raster Calculator to determine which cells were classified similarly by both methods (as either clear or sedimented) and which ones were classified differently. Because only $6.2 \%$ of cells from 25 July 1986, $4.2 \%$ of cells from 3 May 2014, and 4.5\% of cells from 4 June 2014 (out of over 80,000 cells examined per date) displayed a discrepancy between the two independent methods, we feel confident that playa water can be accurately categorized as either clear or sedimented from satellite imagery in this manner (Figure 2b). Such a distinction is also possible by observers in the field (e.g., as in Figure 2a), but finer levels of separation into multiple sedimentation classes (e.g., high, medium, and low) have not been reliable because sedimentation is a naturally continuous phenomenon, and there may be differences in turbidity within different portions of the same playa. Because there is a lack of standard (e.g., EPA) thresholds of turbidity that elicit biological effects (likely because such effects are species-specific), our binary classification is a logical approach to quantifying sedimentation over a large scale and relating that to land use. We used the ArcMap classification products for subsequent analyses because they were already in a native format for subsequent analytical steps in ArcMap, with no other processing needed.

Many studies in other wetland systems that used satellite imagery to quantify water clarity also typically used simultaneous field-collected turbidity data to refine predictive analytical models (mainly regression equations) of reflectance values, or to calibrate unsupervised classification methods for examining water clarity [34,35,61], although such data are not essential [51]. Rapidly obtained ground-truthed turbidity data from playas over a large area are effectively impossible to obtain, however, because over $90 \%$ of playas are on private property [19], often with absentee landowners, making land access extremely difficult. The fact that most playas are privately owned and occur across a large (multi-state) geographic extent creates logistical impediments to characterizing and measuring wetland state, condition, or functioning simultaneously, which is why satellite examination of expansive and dynamic wetland systems is necessary $[17,62]$.

\section{Conclusions}

Playas are temporary, runoff-fed wetlands of the Great Plains of North America that are regionally important in supporting biodiversity. Sedimentation (primarily from human activities such as irrigated tillage agriculture) is a major threat to playas and their associated biota because infill decreases the volume of water that can be stored, even to the point of causing the basin to be entirely filled with earth, and creates turbid water. We undertook the first assessment of turbidity in playa waters to quantify prevalence of sedimentation and to examine the influence of surrounding land use on the occurrence of turbidity. We used satellite imagery to examine the prevalence of turbidity in 8372 playa basins in northwest Texas (a region with very high playa density that had been experiencing severe drought). We examined these basins on four dates across a 29-year span. These dates included a relatively wet date from 1986 (when most playa basins were expected to be wet but relatively less affected by sediment accrual), a date during exceptional drought in 2014 (when most playa basins were expected to be dry), a date in 2014 immediately after the drought was broken (when playa basins were expected to be full and highly sedimented), and a date one year later in 2015 that may have given sediments a chance to settle out. The majority of playa basins that were examined never held water, even when some ponding should have been expected given high amounts of rainfall in the region. The prevalence of turbid playas varied over time, with over half of the basins examined in 1986 being turbid. There was an increase in total and irrigated cropland in our study area, with a statistically significant association 
between turbidity and land use within $100 \mathrm{~m}$ of a playa: clear playas were associated with more urban development and pasture/grassland, and turbid playas were surrounded mostly by cropland. Even with extensive rains, $64 \%$ of playa basins did not hold water at all, suggesting that sedimentation has already compromised the ability of some playas to function as wetlands. Water monitoring is an ongoing challenge in a rapidly changing world. We showed that using remotely sensed imagery to document how land conversion affects turbidity is particularly effective for widely dispersed and dynamic wetlands that are owned or governed by different entities (e.g., private landowners, state or federal agencies, etc.), especially those that are not actively monitored or managed for conservation.

Acknowledgments: Funding was provided by NSF-Macrosystems Biology grant 1340548 (“Collaborative Research: Climatic and Anthropogenic Forcing of Wetland Landscape Connectivity in the Great Plains") and NSF-Proactive Recruitment in Introductory Science and Mathematics grant 1035096 ("RMR-TTU: Recruitment, Mentoring, and Research in Mathematics and Science at Texas Tech University"). Scott M. Starr was funded in part by a Water Conservation Research Fellowship, Texas Tech University Dissertation Completion Fellowship, and The CH Foundation Doctoral Fellowship. Lucas J. Heintzman was funded in part by an Elo and Olga Urbanovsky Assistantship. We thank Keegan Gossett (NSF-PRISM Scholar, Dept. Mathematics and Statistics, Texas Tech University) for assistance in data processing, Carlos Portillo-Quintero (Dept. Natural Resources Management, Texas Tech University) for analytical assistance and advice, and comments from three anonymous reviewers.

Author Contributions: Scott M. Starr, Lucas J. Heintzman, and Nancy E. McIntyre conceived, designed, and performed the experiments; Scott M. Starr and Nancy E. McIntyre analyzed the data; Lucia S. Barbato and Kevin R. Mulligan contributed datasets and analytical advice; and Nancy E. McIntyre wrote the paper. All authors edited the paper.

Conflicts of Interest: The authors declare no conflict of interest.

\section{References}

1. Ritchie, J.C. Sediment, fish, and fish habitat. J. Soil Water Conserv. 1972, 27, 124-125.

2. Richter, B.D.; Braun, D.P.; Mendelson, M.A.; Master, L.L. Threats to imperiled freshwater fauna. Conserv. Biol. 1997, 11, 1081-1093. [CrossRef]

3. Martin, D.B.; Hartman, W.A. The effect of cultivation on sediment composition and deposition in prairie pothole wetlands. Water Air Soil Pollut. 1987, 34, 45-53. [CrossRef]

4. Daniel, D.W.; Smith, L.M.; Haukos, D.A.; Johnson, L.A.; McMurry, S.T. Land use and Conservation Reserve Program effects on the persistence of playa wetlands in the High Plains. Environ. Sci. Technol. 2014, 48, 4282-4288. [CrossRef] [PubMed]

5. Bolen, E.G.; Smith, L.M.; Schramm, H.L., Jr. Playa lakes: Prairie wetlands of the Southern High Plains. BioScience 1989, 39, 615-623. [CrossRef]

6. Haukos, D.A.; Smith, L.M. The importance of playa wetlands to biodiversity of the Southern High Plains. Landsc. Urban Plan. 1994, 28, 83-98. [CrossRef]

7. Smith, L.M. Playas of the Great Plains; University of Texas Press: Austin, TX, USA, 2003.

8. Yechieli, Y.; Wood, W.W. Hydrogeologic processes in saline systems: Playas, sabkhas, and saline lakes. Earth Sci. Rev. 2002, 58, 343-365. [CrossRef]

9. Fraser, L.H., Keddy, P.A., Eds.; The World's Largest Wetlands: Ecology and Conservation; Cambridge University Press: New York, NY, USA, 2005.

10. Batzer, D.P., Baldwin, A.H., Eds.; Wetland Habitats of North America: Ecology and Conservation Concerns; University of California Press: Berkeley, CA, USA, 2012.

11. Wright, C.K.; Wimberly, M.C. Recent land use change in the Western Corn Belt threatens grasslands and wetlands. Proc. Natl. Acad. Sci. USA 2013, 110, 4134-4139. [CrossRef] [PubMed]

12. Bassi, N.; Kumar, M.D.; Sharma, A.; Pardha-Saradhi, P. Status of wetlands in India: A review of extent, ecosystem benefits, threats and management strategies. J. Hydrol. Reg. Stud. 2014, 2, 1-19. [CrossRef]

13. Haukos, D.A.; Smith, L.M. Ecology of Playa Lakes. In Fish and Wildlife Leaflet 13.3.7, Waterfowl Management Handbook; U.S. Fish and Wildlife Service: Washington, DC, USA, 1992; pp. 1-7.

14. United States Department of Agriculture, Natural Resources Conservation Service. Field Indicators of Hydric Soils in the United States; Version 7.0; Vasilas, L.M., Hurt, G.W., Noble, C.V., Eds.; United States Department of Agriculture, Natural Resources Conservation Service: Washington, DC, USA, 2010. 
15. Mason, R. The cotton kingdom and the city of Lubbock: South Plains agriculture in the postwar era. In Lubbock: From Town to City; Graves, L.L., Ed.; West Texas Museum Association: Lubbock, TX, USA, 1986; pp. 1-55.

16. Luo, H.-R. Effects of Land Use on Sediment Deposition in Playas. Master's Thesis, Texas Tech University, Lubbock, TX, USA, 1994.

17. Collins, S.D.; Heintzman, L.J.; Starr, S.M.; Wright, C.K.; Henebry, G.M.; McIntyre, N.E. Hydrological dynamics of temporary wetlands in the southern Great Plains as a function of surrounding land use. J. Arid Environ. 2014, 109, 6-14. [CrossRef]

18. USDA Census of Agriculture. Available online: http://www.agcensus.usda.gov (accessed on 22 October 2015).

19. Haukos, D.A.; Smith, L.M. Past and future impacts of wetland regulations on playas. Wetlands 2003, 23, 577-589. [CrossRef]

20. Musick, J.T.; Pringle, F.B.; Harman, W.L.; Stewart, B.A. Long-term irrigation trends-Texas High Plains. Appl. Eng. Agric. 1990, 6, 717-724. [CrossRef]

21. Tsai, J.-S.; Venne, L.S.; McMurry, S.T.; Smith, L.M. Influences of land use and wetland characteristics on water loss rates and hydroperiods of playas in the Southern High Plains, USA. Wetlands 2007, 27, 683-692. [CrossRef]

22. O'Connell, J.L.; Johnson, L.A.; Daniel, D.W.; McMurry, S.T.; Smith, L.M.; Haukos, D.A. Effects of agricultural tillage and sediment accumulation on emergent plant communities in playa wetlands of the U.S. High Plains. J. Environ. Manag. 2013, 120, 10-17. [CrossRef] [PubMed]

23. Tang, Z.; Gu, Y.; Drahota, J.; LaGrange, T.; Bishop, A.; Kuzila, M.S. Using fly ash as a marker to quantify culturally-accelerated sediment accumulation in playa wetlands. J. Am. Water Resour. Assoc. 2015. [CrossRef]

24. Luo, H.-R.; Smith, L.M.; Haukos, D.A.; Allen, B.L. Sources of recently deposited sediments in playa wetlands. Wetlands 1999, 19, 176-181. [CrossRef]

25. Luo, H.-R.; Smith, L.M.; Allen, B.L.; Haukos, D.A. Effects of sedimentation on playa wetland volume. Ecol. Appl. 1997, 7, 247-252. [CrossRef]

26. Tsai, J.-S.; Venne, L.S.; McMurry, S.T.; Smith, L.M. Vegetation and land use impact on water loss rate in playas of the Southern High Plains. Wetlands 2010, 30, 1107-1116. [CrossRef]

27. Daniel, D.W.; Smith, L.M.; McMurry, S.T. Land use effects on sedimentation and water storage volume in playas of the rainwater basin of Nebraska. Land Use Policy 2015, 42, 426-431. [CrossRef]

28. Johnson, L.A.; Haukos, D.A.; Smith, L.M.; McMurry, S.T. Physical loss and modification of Southern Great Plains playas. J. Environ. Manag. 2012, 112, 275-283. [CrossRef] [PubMed]

29. Johnson, L.A.; Haukos, D.A.; Smith, L.M.; McMurry, S.T. Loss of playa wetlands caused by reclassification and remapping of hydric soils on the Southern High Plains. Wetlands 2011, 31, 483-492. [CrossRef]

30. Smith, L.M.; Haukos, D.A.; McMurry, S.T.; LaGrange, T.; Willis, D. Ecosystems services provided by playas in the High Plains: Potential influences of USDA conservation programs. Ecol. Appl. 2011, 21. [CrossRef]

31. Burris, L.; Skagen, S.K. Modeling sediment accumulation in North American playa wetlands in response to climate change, 1940-2100. Clim. Chang. 2013, 117, 69-83. [CrossRef]

32. Gitz, D.; Zartman, R.E.; Villarreal, C.J.; Rainwater, K.; Smith, L.M.; Ritchie, G. Sediment accumulation in semi-arid wetlands of the Texas Southern High Plains. Tex. J. Agric. Nat. Resour. 2015, 28, 70-81.

33. Hall, D.L.; Sites, R.W.; Fish, E.B.; Mollhagen, T.R.; Moorhead, D.L.; Willig, M.R. Playas of the Southern High Plains: The macroinvertebrate fauna. In Invertebrates in Freshwater Wetlands of North America: Ecology and Management; Batzer, D.P., Rader, R.B., Wissinger, S.A., Eds.; John Wiley and Sons: New York, NY, USA, 1999; pp. 635-665.

34. Kloiber, S.M.; Brezonik, P.L.; Bauer, M.E. Application of Landsat imagery to regional-scale assessments of lake clarity. Water Res. 2002, 36, 4330-4340. [CrossRef]

35. Kloiber, S.M.; Brezonik, P.L.; Olmanson, L.G.; Bauer, M.E. A procedure for regional lake water clarity assessment using Landsat multispectral data. Remote Sens. Environ. 2002, 82, 38-47. [CrossRef]

36. Brezonik, P.; Menken, K.D.; Bauer, M. Landsat-based remote sensing of lake water quality characteristics, including chlorophyll and colored dissolved organic matter (CDOM). Lake Reserv. Manag. 2005, 21, 373-382. [CrossRef]

37. Olmanson, L.G.; Bauer, M.E.; Brezonik, P.L. A 20-year Landsat water clarity census of Minnesota's 10,000 lakes. Remote Sens. Environ. 2008, 112, 4086-4097. [CrossRef] 
38. O'Dell, J.W., Ed.; Method 180.1: Determination of Turbidity by Nephelometry; United States Environmental Protection Agency: Cincinnati, OH, USA, 1993.

39. Henley, W.F.; Patterson, M.A.; Neves, R.J.; Lemly, A.D. Effects of sedimentation and turbidity on lotic food webs: A concise review for natural resource managers. Rev. Fish. Sci. 2000, 8, 125-139. [CrossRef]

40. Jurik, T.W.; Wang, S.-C.; van der Valk, A.G. Effects of sediment load on seedling emergence from wetland seed banks. Wetlands 1994, 14, 159-165. [CrossRef]

41. Gleason, R.A.; Euliss, N.H., Jr.; Hubbard, D.E.; Duffy, W.G. Effects of sediment load on emergence of aquatic invertebrates and plants from wetland soil egg and seed banks. Wetlands 2003, 23, 26-34. [CrossRef]

42. Anderson, J.T.; Smith, L.M. Persistence and colonization strategies of playa wetland invertebrates. Hydrobiologia 2004, 513, 77-86. [CrossRef]

43. Sublette, J.E.; Sublette, M.S. The limnology of playa lakes on the Llano Estacado, New Mexico and Texas. Southwest. Nat. 1967, 12, 369-406. [CrossRef]

44. Scheffer, M. Multiplicity of stable states in freshwater systems. Hydrobiologia 1990, 200, 475-486. [CrossRef]

45. Tsai, J.-S. Local and Landscape Factor Influences on Avian Community Composition in Playas of the Southern High Plains. Ph.D. Thesis, Texas Tech University, Lubbock, TX, USA, 2007.

46. Gray, M.J.; Smith, L.M.; Leyva, R.I. Influence of agricultural landscape structure on a Southern High Plains amphibian assemblage. Landsc. Ecol. 2004, 19, 719-729. [CrossRef]

47. Madej, M.A.; Wilzbach, M.; Cummins, K.; Ellis, C.; Hadden, S. The significance of suspended organic sediments to turbidity, sediment flux, and fish-feeding behavior. In Proceedings of the Redwood Region Forest Science Symposium: What Does The Future Hold? Albany, CA, USA, 2007; pp. 383-388.

48. Lavery, P.; Pattiaratchi, C.; Wyllie, A.; Hick, P. Water quality monitoring in estuarine waters using the Landsat Thematic Mapper. Remote Sens. Environ. 1993, 467, 268-280. [CrossRef]

49. Cox, R.M.; Forsythe, R.D.; Vaughan, G.E.; Olmsted, L.L. Assessing water quality in the Catawba River reservoirs using Landsat Thematic Matter satellite data. Lake Reserv. Manag. 1998, 14, 405-416. [CrossRef]

50. Bustamante, J.; Pacios, F.; Díaz-Delgado, R.; Aragonés, D. Predictive models of turbidity and water depth in the Doñana marshes using Landsat TM and ETM+ images. J. Environ. Manag. 2009, 90, 2219-2225. [CrossRef] [PubMed]

51. Odermatt, D.; Gitelson, A.; Brando, V.E.; Schaepman, M. Review of constituent retrieval in optically deep and complex waters from satellite imagery. Remote Sens. Environ. 2012, 118, 116-126. [CrossRef]

52. National Weather Service. Available online: http://www.srh.noaa.gov/lub/?n=climate-klbb-pcpn (accessed on 22 October 2015).

53. US Drought Monitor. Available online: http://droughtmonitor.unl.edu/ (accessed on 22 October 2015).

54. Playa Lakes Joint Venture Playas Data Layer. Available online: http://pljv.org/PPv4_MapBook/ probable_playas_v4_shapefiles.zip (accessed on 5 November 2015).

55. USGS Global Visualization Viewer. Available online: http://glovis.usgs.gov (accessed on 25 October 2015).

56. Ozesmi, S.L.; Bauer, M.E. Satellite remote sensing of wetlands. Wetl. Ecol. Manag. 2002, 10, 381-402. [CrossRef]

57. Cariveau, A.B.; Pavlacky, D.C., Jr.; Bishop, A.A.; LaGrange, T.G. Effects of surrounding land use on playa inundation following intense rainfall. Wetlands 2011, 31, 65-73. [CrossRef]

58. Playas and Wetlands Database. Available online: http://gis.ttu.edu/pwd (accessed on 25 October 2015).

59. Mulligan, K.R.; Barbato, L.S.; Seshadri, S. Playas and Wetlands Database. Available online: http:/ / gis.ttu.edu/pwd/PlayasDocument.pdf (accessed on 25 October 2015).

60. Fish, E.B.; Atkinson, E.L.; Mollhagen, T.R.; Shanks, C.H.; Brenton, C.M. Playa Lakes Digital Database for the Texas Portion of the Playa Lakes Joint Venture Region; Texas Tech University: Lubbock, TX, USA, 1998.

61. Sawaya, K.E.; Olmanson, L.G.; Heinert, N.J.; Brezonik, P.L.; Bauer, M.E. Extending satellite remote sensing to local scales: Land and water resource monitoring using high-resolution imagery. Remote Sens. Environ. 2003, 88, 144-156. [CrossRef]

62. Alsdorf, D.; Lettenmaier, D.; Vörösmarty, C. The need for global, satellite-based observations of terrestrial surface waters. Eos Trans. Am. Geophys. Union 2003, 84, 275-276. [CrossRef]

63. USDA National Agricultural Statistics Service CropScape. Available online: http://nassgeodata.gmu.edu/ CropScape/ (accessed on 2 February 2015).

64. Bartuszevige, A.M.; Pavlacky, D.C.; Burris, L.; Herbener, K. Inundation of playa wetlands in the western Great Plains relative to landcover context. Wetlands 2012, 32, 1103-1113. [CrossRef] 
65. Ruiz, L.J.; Parikh, N.N.; Heintzman, L.J.; Collins, S.D.; Starr, S.M.; Wright, C.K.; Henebry, G.M.; van Gestel, N.; McIntyre, N.E. Dynamic connectivity of temporary wetlands in the southern Great Plains. Landsc. Ecol. 2014, 29, 507-516. [CrossRef]

66. Van der Kamp, G.; Hayashi, M.; Gallén, D. Comparing the hydrology of grassed and cultivated catchments in the semi-arid Canadian prairies. Hydrol. Process. 2003, 17, 559-575. [CrossRef]

67. Van der Kamp, G.; Stolte, W.J.; Clark, R.G. Drying out of small prairie wetlands after conversion of the catchments to permanent brome grass. Hydrol. Sci. J. 1999, 44, 387-397. [CrossRef]

68. Voldseth, R.A.; Johnson, W.C.; Gilmanov, T.; Guntenspergen, G.R.; Millett, B.V. Model estimates of land-use effects on water levels of northern prairie wetlands. Ecol. Appl. 2007, 17, 527-540. [CrossRef] [PubMed]

69. Voldseth, R.A.; Johnson, W.C.; Guntenspergen, G.R.; Gilmanov, T.; Millett, B.V. Adaptation of farming practices could buffer effects of climate change on northern prairie wetlands. Wetlands 2009, 29, 635-647. [CrossRef]

70. Skagen, S.K.; Melcher, C.P.; Haukos, D.A. Reducing sedimentation of depressional wetlands in agricultural landscapes. Wetlands 2008, 28, 594-604. [CrossRef]

71. Johnston, C.A. Sediment and nutrient retention by freshwater wetlands: Effects on surface water quality. Crit. Rev. Environ. Control 1991, 21, 491-565. [CrossRef]

72. Dosskey, M.G. Toward quantifying water pollution abatement in response to installing buffers on crop land. Environ. Manag. 2001, 28, 577-598. [CrossRef] [PubMed]

(C) 2016 by the authors; licensee MDPI, Basel, Switzerland. This article is an open access article distributed under the terms and conditions of the Creative Commons by Attribution (CC-BY) license (http:/ / creativecommons.org/licenses/by/4.0/). 